\title{
Patients' perception about opioids and addiction in South Korea
}

\author{
Cho Long Kim ${ }^{1}$, Sung Jun Hong ${ }^{2}$, Yun Hee Lim³, Jae Hun Jeong ${ }^{4}$, Ho Sik Moon ${ }^{5}$, Hey Ran Choi ${ }^{6}$, \\ Sun Kyung Park ${ }^{7}$, Jung Eun Kim ${ }^{8}$, Hakjong You ${ }^{2}$, and Jae Hun Kim ${ }^{1}$
}

\author{
'Department of Anesthesiology and Pain Medicine, Konkuk University School of Medicine, Seoul, Korea \\ ${ }^{2}$ Department of Anesthesiology and Pain Medicine, Kangdong Sacred Heart Hospital, Seoul, Korea \\ ${ }^{3}$ Department of Anesthesiology and Pain Medicine, Inje University Sanggye Paik Hospital, Seoul, Korea \\ ${ }^{4}$ Department of Anesthesiology and Pain Medicine, Jeong-clinic, Seoul, Korea \\ ${ }^{5}$ Department of Anesthesiology and Pain Medicine, The Catholic University of Korea, Eunpyeong St. Mary's Hospital, Seoul, Korea \\ ${ }^{6}$ Department of Anesthesiology and Pain Medicine, Inje University Seoul Paik Hospital, Seoul, Korea \\ ${ }^{7}$ Department of Anesthesiology and Pain Medicine, Jeju National University School of Medicine, Jeju, Korea \\ ${ }^{8}$ Department of Anesthesiology and Pain Medicine, Hallym University Kangnam Sacred Heart Hospital, Seoul, Korea
}

Received January 2, 2020

Revised April 1, 2020

Accepted April 3, 2020

Handling Editor: Ji Seok Baik

\section{Correspondence}

Jae Hun Kim

Department of Anesthesiology and Pain

Medicine, Konkuk University Medical

Center, Konkuk University School

of Medicine, 120-1, Neungdong-ro,

Gwangjin-gu, Seoul 05030, Korea

Tel: $+82-2-2030-5749$

Fax: +82-2-2030-5449

E-mail: painfree@kuh.ac.kr
Background: Chronic pain affects approximately $22 \%$ of the world's population. Opioids can be useful in chronic pain management. However, some patients have negative perception of opioids. The purpose of this research was to evaluate patients' perception about opioids and investigate problems associated with prescribing and taking opioids in South Korea.

Methods: Patients who visited a pain clinic in 14 university hospitals of South Korea from September through October 2018 were asked to complete anonymous questionnaires about taking opioids.

Results: Of the 368 patients that were surveyed (female 53.3\%, male $46.7 \%$ ), $56.8 \%$ were prescribed opioids. In the opioid group, $92.8 \%$ patients had heard of opioids from their doctor and $72.6 \%$ of them had a positive perception about opioids. The side effects associated with opioid use were constipation (35.4\%), dizziness (24.6\%), nausea and vomiting (17.4\%), dysuria (6.2\%), and addiction (2.0\%). In the no opioid group, the primary sources of information about opioids were doctors $(49.2 \%)$, mass media (30.8\%), and the internet (16.2\%). The main reasons why $39.0 \%$ patients did not take opioids were fear of addiction (57.7\%) and side effects (38.5\%). There were $71.5 \%$ and $60.9 \%$ patients in the opioid and no opioid group, respectively, who wished to take opioids when their numeric rating scale pain score was $\geq 7$.

Conclusions: Perception of opioids among patients who take them was either neutral or positive. However, $39.0 \%$ patients who have not been prescribed opioids did not want an opioid prescription, citing fear of addiction and side effects as the primary reasons.

Key Words: Analgesics, Opioid; Behavior, Addictive; Chronic Pain; Drug-Related Side Effects and Adverse Reactions; Opioid-Related Disorders; Outpatients; Pain Management; Physicians; Surveys and Questionnaires. (a) This is an open-access article distributed under the terms of the Creative Commons Attribution Non-Commercial License (http://creativecommons.org/licenses/by-nc/4.0/), which permits unrestricted non-commercial use, distribution, and reproduction in any medium, provided the original work is properly cited.

(C) The Korean Pain Society, 2020
Author contributions: Cho Long Kim: Writing/manuscript preparation; Sung Jun Hong: Study conception, Supervision; Yun Hee Lim: Writing/ manuscript preparation; Jae Hun Jeong: Writing/manuscript preparation; Ho Sik Moon: Writing/manuscript preparation; Hey Ran Choi: Writing/ manuscript preparation; Sun Kyung Park: Writing/manuscript preparation; Jung Eun Kim: Writing/manuscript preparation; Hakjong You: Writing/ manuscript preparation; Jae Hun Kim: Study conception, Writing/manuscript preparation. 


\section{INTRODUCTION}

According to the World Health Organization, the prevalence of chronic pain was approximately $22 \%$ worldwide [1]. Due to prolonged life expectancy and an increase in the proportion of older people in the society, the number of people suffering from chronic pain is expected to increase continuously [2]. Acute pain can have a protective effect on the body whereas chronic pain has a negative effect on the quality of life. Chronic pain may lead to a decrease in daily activities and an increase in cardiovascular complications, depression, and sleep disturbance [3-5].

Treatment of underlying causes is necessary to relieve pain; however, it is impossible in many patients who have intractable pain. Pain can be chronic and severe in some patients, and thus, non-opioid analgesics such as acetaminophen or non-steroidal anti-inflammatory drugs may not provide adequate pain relief. Opioids are the most potent analgesics, and an opioid therapy can effectively reduce chronic pain and improve the health-related quality of life in patients with intractable pain. Guidelines from both the Neuropathic Pain Special Interest Group of the International Association for the Study of Pain and the European Federation of Neurological Societies Task Force recommend opioids as the second- or third-line treatment for neuropathic pain $[6,7]$. In addition to advantages, opioids have disadvantages that include pharmacological side effects and socioeconomic problems such as addiction and misuse [8]. According to a systematic review of opioid use for non-cancer pain, dry mouth, nausea, and constipation were the most common adverse events [9]. Opioid treatment was discontinued in a substantial proportion $(22 \%)$ of patients because of adverse events [9]. However, more than the evidence-based concerns, misconceptions about opioids may interfere with the necessary treatment for pain control. Some patients are reluctant to take pain medications due to fear of addiction and/or of being thought of as an addict, fear of analgesic tolerance, and side-effects $[10,11]$. Furthermore, some patients in Korea have a fear of addiction in regards to taking their prescribed opioid medications and some of these patients have shared this concern with their doctors [12].

Opioid prescriptions are increasing in Korea. One survey suggested that opioid consumption rose from 1995 to 2000 [13]. Another survey reported that the prevalence of chronic use of weak and strong opioids increased gradually from 2002 to 2015 [14]. Recently, the American Pain Society officially shutdown and filed for bankruptcy due to issues regarding opioid medication and abuse [15]. The Korean Pain Society conducted a survey to assess the perception of opioids (positive or negative), whether the patients distinguished between medically prescribed opioids and illegally distributed drugs, and if the patients would follow doctor's instructions when opioids are prescribed to them. In the current survey, we investigated patients' perception about opioids, and attempted to identify the problems associated with prescribing and taking opioids in South Korea.

\section{MATERIALS AND METHODS}

The ethical approval for this study was waived by the Institutional Review Board of the Konkuk University Medical Center (IRB No. 2019-12-014). The survey was conducted by the Publicity Committee of the Korean Pain Society from September through October 2018. On the basis of the results of this anonymous survey, this manuscript was drafted in 2019. Patients who visited a pain clinic in 14 university hospitals in Korea were asked to complete anonymous questionnaires about taking opioids. Patients were informed that the purpose of this questionnaire was to investigate the perceptions of Korean patients regarding opioids and there would be no personal advantages or disadvantages, irrespective of whether they agreed or disagreed with this survey. The survey was then conducted only with patients who agreed to the survey. Patients who did not agree to participate in the survey were excluded.

The questionnaire consisted of the following questions (Appendix): sex, age, the disease a patient is suffering from, period of treatment, experience of being prescribed opioids, side effects after taking opioids, degree of explanation from their doctor when they were prescribed opioids, perception of opioids, relevance of the legally allowed and insured duration of opioid prescription and dosage, whether the participant accepted the prescription of opioids, and if not, the reason for refusing opioid therapy, their source of getting information about opioids, whether they could differentiate between medically prescribed and illegally distributed opioids, and the numeric rating scale (NRS) pain score for deciding to take opioids. We distinguished patients who were actually prescribed opioids from those who were not, and each group was asked different questions to identify differences between the two groups including the overall perception about opioids. Patients who were prescribed opioids were administered a questionnaire assessing the side effects experienced by them, the extent of information they received regarding opioids from their doctor, and how they perceived opioids. Furthermore, their opinions regarding current restrictions on opioid prescription were obtained. On the other hand, patients who were not prescribed opioids were asked regarding their source of opioid knowledge, and whether they would follow the doctor's opioid prescription. 


\section{RESULTS}

A total of 368 patients from 14 university hospitals completed the questionnaires. Distribution of the sex, age, disease, and treatment duration of patients who responded to the questionnaires are summarized in Table 1. Of the 368 patients, 209 (56.8\%, opioid group) were prescribed opioids whereas 159 (43.2\%, no opioid group) were not prescribed (Fig. 1).

In the opioid group, the side effects after taking opioids were constipation ( $n=69,35.4 \%)$, dizziness $(n=48,24.6 \%)$, nausea and vomiting $(\mathrm{n}=34,17.4 \%)$, dysuria $(\mathrm{n}=12,6.2 \%)$, addiction ( $\mathrm{n}=4,2.0 \%)$, and others $(\mathrm{n}=6,3.1 \%)$. Twentytwo patients $(\mathrm{n}=22,11.3 \%)$ had no side effects (excluding 14 non-respondents) (Fig. 2). In the opioid group ( $n=206$, after excluding 3 non-respondents), 161 patients (78.1\%) received a good explanation about opioids and their side

Table 1. Demographic Data

\begin{tabular}{|c|c|c|}
\hline Demographic variable & Category & $\begin{array}{c}\text { No. of patients } \\
(\%)\end{array}$ \\
\hline \multirow[t]{2}{*}{$\operatorname{Sex}(n=368)$} & $M$ & $172(46.7)$ \\
\hline & $\mathrm{F}$ & 196 (53.3) \\
\hline \multirow[t]{7}{*}{ Age $(n=368)$} & $20 s$ & $19(5.2)$ \\
\hline & $30 \mathrm{~s}$ & 66 (17.9) \\
\hline & $40 s$ & $76(20.7)$ \\
\hline & $50 s$ & $83(22.6)$ \\
\hline & $60 s$ & 66 (17.9) \\
\hline & $70 \mathrm{~s}$ & 41 (11.1) \\
\hline & $\geq 80$ & $17(4.6)$ \\
\hline \multirow{6}{*}{$\begin{array}{l}\text { Disease ( } n=345 \text {, excluding } 23 \\
\text { non-respondents) }\end{array}$} & Spinal or joint pain & 166 (48.1) \\
\hline & $\begin{array}{l}\text { Complex regional } \\
\text { pain syndrome }\end{array}$ & 76 (22.0) \\
\hline & $\begin{array}{l}\text { Postherpetic } \\
\text { neuralgia }\end{array}$ & $40(11.6)$ \\
\hline & Fibromyalgia & $31(9.0)$ \\
\hline & $\begin{array}{l}\text { Peripheral } \\
\text { neuropathy }\end{array}$ & $26(7.5)$ \\
\hline & Cancer pain & $6(1.8)$ \\
\hline \multirow{5}{*}{$\begin{array}{l}\text { Period of treatment ( } \mathrm{n}=366 \text {, } \\
\text { excluding } 2 \text { non-respondents) }\end{array}$} & $<6 \mathrm{mo}$ & $99(27.0)$ \\
\hline & $6 \mathrm{mo} \leq,<1 \mathrm{yr}$ & 48 (13.1) \\
\hline & $1 \mathrm{yr} \leq,<3 \mathrm{yr}$ & $76(20.8)$ \\
\hline & $3 \mathrm{yr} \leq,<5 \mathrm{yr}$ & $63(17.2)$ \\
\hline & $5 y r \geq$ & 80 (21.9) \\
\hline
\end{tabular}

effects from their doctors, 30 patients $(14.6 \%)$ received a rough explanation, and 15 patients $(7.3 \%)$ did not receive any explanation. Among 201 patients (excluding 8 nonrespondents), $21.9 \%, 50.7 \%, 20.9 \%$, and $6.5 \%$ of patients had a very positive, positive, neutral, and negative or very negative perception of opioids, respectively (Fig. 3). In the opioid group, among 200 patients (excluding 9 nonrespondents), 20 (10.0\%), 46 (23.0\%), 18 (9.0\%), 100 (50.0\%), and 16 patients $(8.0 \%)$ were prescribed opioids for $1,2,3$, 4 , and above 4 weeks at a time, respectively. Currently, opioids can only be prescribed for up to 30 days in Korea,

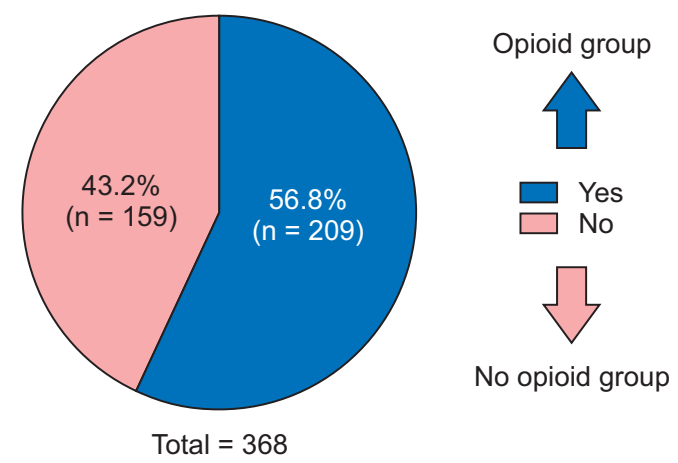

Fig. 1. Have you ever been prescribed opioids? (asked in both the opioid groups).

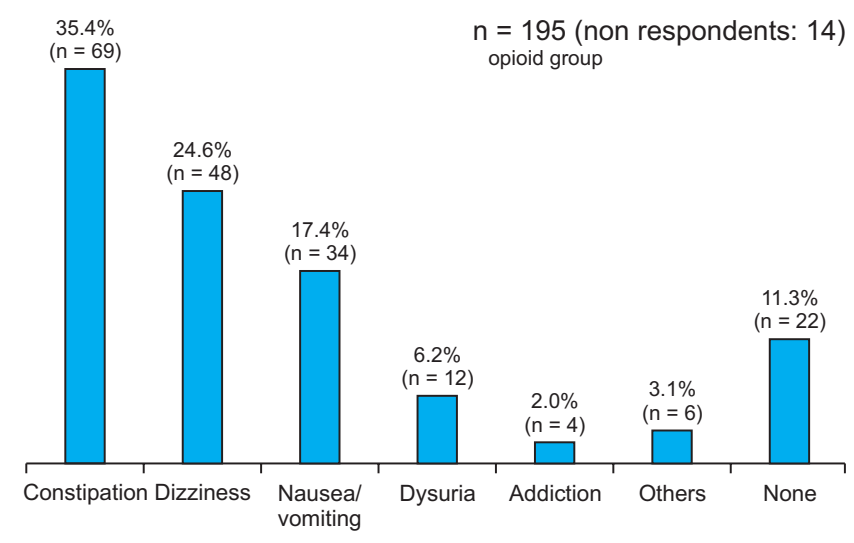

Fig. 2. What are the most severe side effects that you have experienced? (asked in the opioid group).
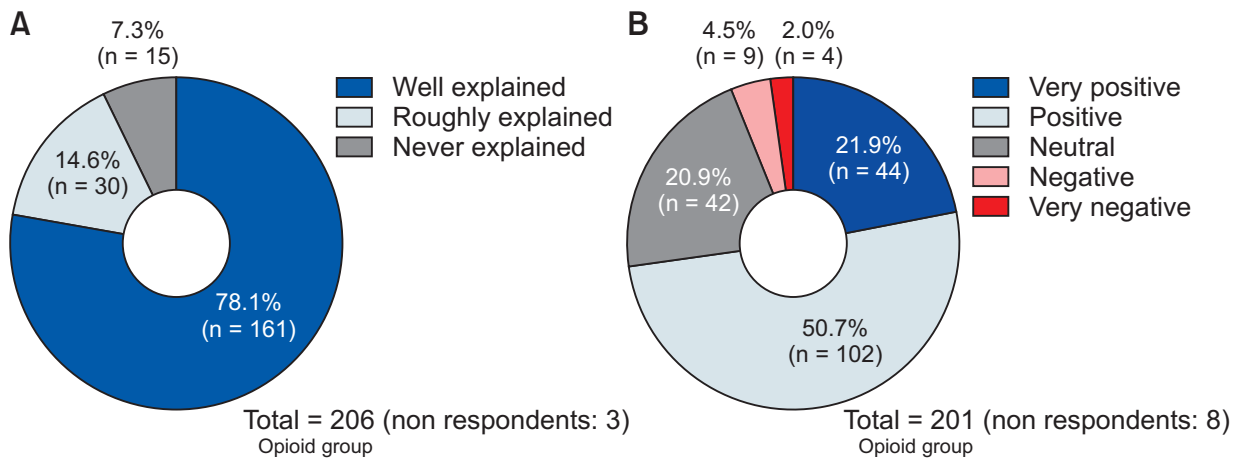

Fig. 3. (A) Did your doctor ask you regarding opioids and explain their side effects? (asked in the opioid group). (B) What is your perception regarding opioid medication? (asked in the opioid group). 


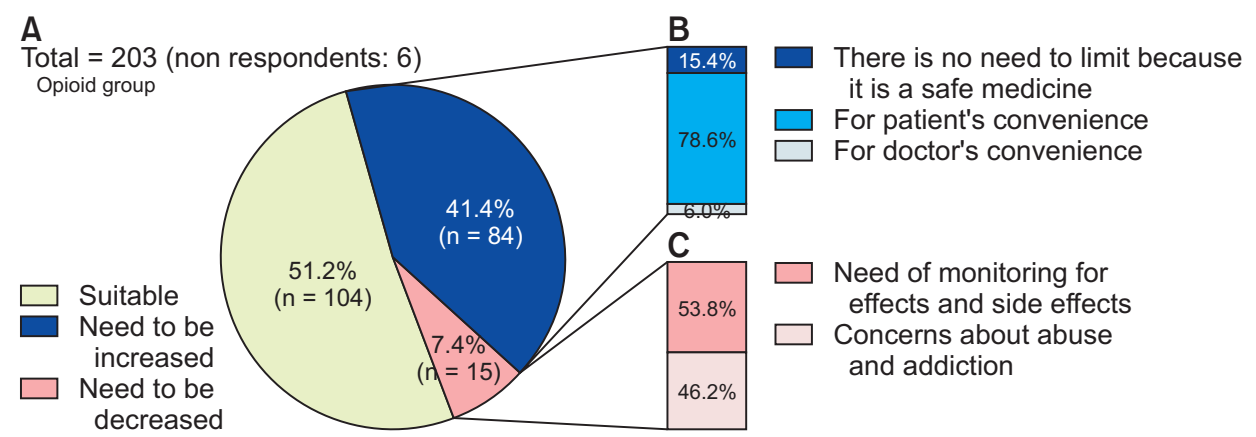

Fig. 4. (A) In Korea, public health insurance provides coverage for the prescription of opioids up to 30 days for the non-cancer pain treatment. What is your opinion regarding this limit? (asked in the opioid group). (B) If you think this limit should be increased, then please tell us why? (C) If you think this limit should be decreased, then please tell us why?

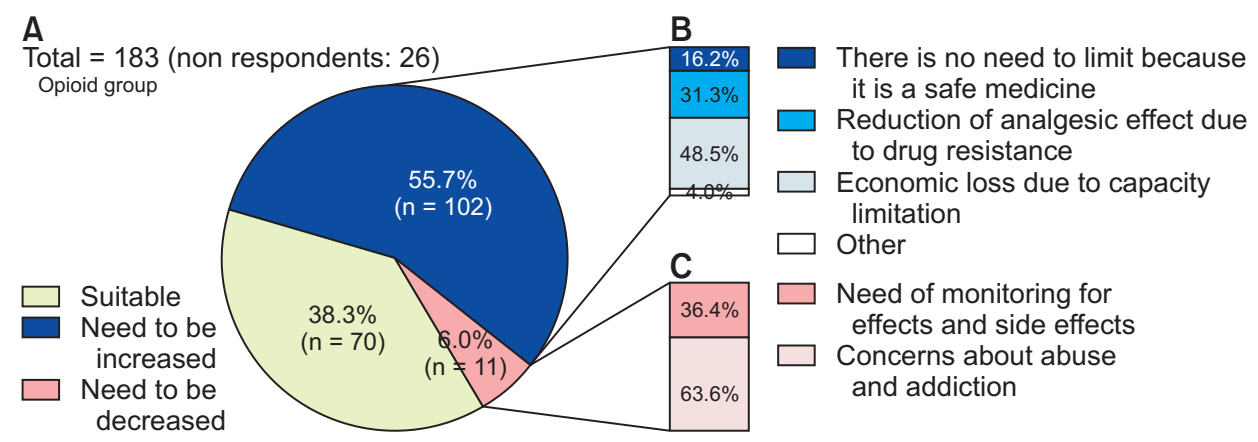

Fig. 5. (A) In Korea, public health insurance provides coverage for opioid prescription for pain treatment. Insurance covered opioid dosage is non-restricted for the cancer pain treatment, but it is limited for the non-cancer pain treatment. What is your opinion regarding this limit on opioid dosage? (asked in the opioid group). (B) If you think insurable prescription dosages should be increased, then please tell us why? (C) If you think insurable prescription dosages should be decreased, then please tell us why?

because of the public healthcare insurance limitations. When patients in the opioid group were asked about their opinion on opioids, 203 patients responded (excluding 6 non-respondents), 104 (51.2\%) of which thought they were suitable, $84(41.4 \%)$ thought that the government should increase the maximum duration of prescription allowed, and 15 patients $(7.4 \%)$ thought that they should be decreased. Among the respondents who answered that the duration limit should be increased, $78.6 \%$ cited patients' convenience as the reason, whereas proponents of a reduction in the limit (excluding 2 non-respondents) cited concerns about abuse and addiction $(n=6,46.2 \%)$ and the need for monitoring of effects and side effects $(\mathrm{n}=7,53.8 \%)$ as reasons (Fig. 4).

In Korea, public healthcare insurance coverage is possible without the limit on opioid doses for managing cancer pain, but there is a limit on the insurable prescription dose for non-cancer pain management. When patients in the opioid group were asked about the limits on dosage in non-cancer pain, among 183 patients (excluding 26 nonrespondents), 70 patients (38.3\%) thought they are suitable, 102 (55.7\%; complex regional pain syndrome [CRPS], 38 patients; postherpetic neuralgia, 6 patients; peripheral neuropathy, 8 patients; fibromyalgia, 9 patients; cancer pain, 3 patients; spinal or joint pain, 33 patients; patients who didn't answer their disease, 5 patients) thought that insurable prescription dosages need to be increased, and 11 patients $(6.0 \%)$ thought that insurable prescription dosages need to be decreased. When they were asked about reasons why they thought it should be increased, 16 respondents (16.2\%) said that opioids are safe, $31(31.3 \%)$ responded that analgesic effects decreased with time due to development of drug resistance, 48 (48.5\%) responded that such insurance policies put financial burdens on the patient, and 4 (4.0\%) cited others reasons (excluding 3 non-respondents). The patients who thought it should be reduced cited concerns with abuse and addiction $(\mathrm{n}=7$, $63.6 \%$ ) and need for monitoring of effects and side effects (n $=4,36.4 \%$ ) as reasons (Fig. 5).

According to 146 patients in the no opioid group (excluding 13 non-respondents) who were prescribed opioids for their treatment, 89 (61.0\%) said that they would take them and $57(39.0 \%)$ said they would not. The reasons cited for refusal ( $\mathrm{n}=52$, excluding 5 non-respondents) were fear of addiction ( $\mathrm{n}=30,57.7 \%)$, fear of side effects $(\mathrm{n}=20,38.5 \%)$, and other ( $\mathrm{n}=2,3.8 \%$ ) (Fig. 6). When 130 patients of the no 


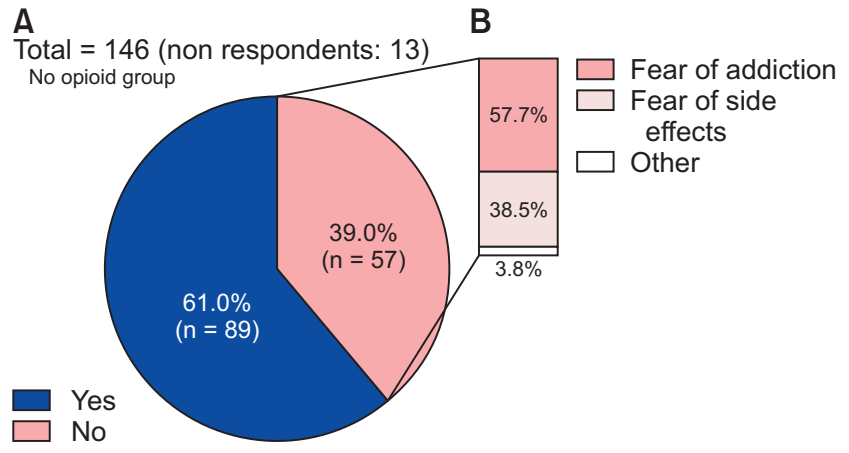

Fig. 6. (A) If your physician informs you regarding the requirement to prescribe opioids for pain control, would you consume them? (asked in the no opioid group). (B) If you deny, then please tell us why?

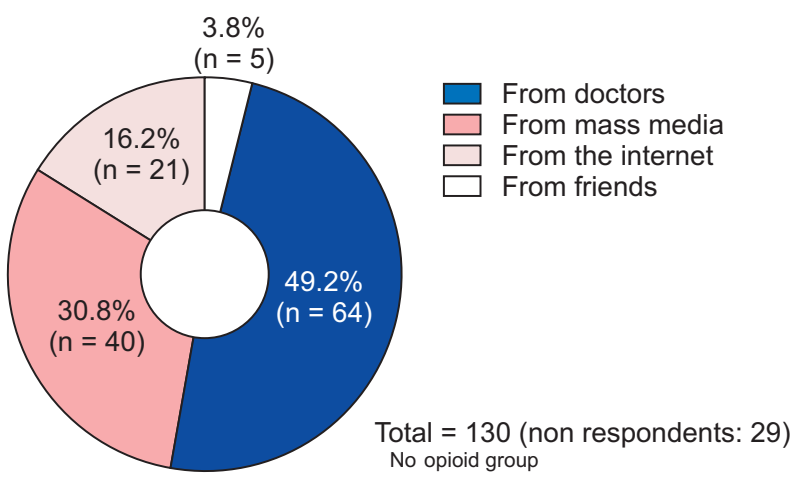

Fig. 7. What is your source of opioid information? (asked in the no opioid group).

opioid group (excluding 29 non-respondents) were asked about their source of information about opioids, 64 (49.2\%), $40(30.8 \%), 21(16.2 \%)$, and $5(3.8 \%)$ said from doctors, mass media, the internet, and friends, respectively (Fig. 7).

Both the opioid and no opioid groups were asked whether they knew that there are differences between medically prescribed opioids and illegally distributed drugs. Among 194 patients in the opioid group (excluding 15 non-respondents), 145 respondents $(74.7 \%)$ said that they knew and 49 (25.3\%) said they did not. In contrast, among 154 patients in the no opioid group (excluding 5 non-respondents), 72 respondents (46.8\%) knew and 82 (53.2\%) did not (Fig. 8). When asked about the pain score at which they would start taking opioids if they were prescribed ( 0 means no pain and 10 means the most severe pain imaginable), among 193 patients in the opioid group (excluding 16 non-respondents), 138 (71.5\%), 29 (15.0\%), 16 (8.3\%), 4 (2.1\%), and 4 patients $(2.1 \%)$ replied $\geq 7,6,5,4$, and 3 points, respectively. Only 2 patients $(1.0 \%)$ replied that they would never take opioids. On the other hand, among 151 patients in the no opioid group (excluding 8 non-respondents), 92 (60.9\%), 23 (15.2\%), $10(6.6 \%), 0(0 \%)$, and 6 patients $(4.0 \%)$ replied $\geq 7$, $6,5,4$, and 3 , respectively, whereas 20 patients $(13.3 \%)$ re-

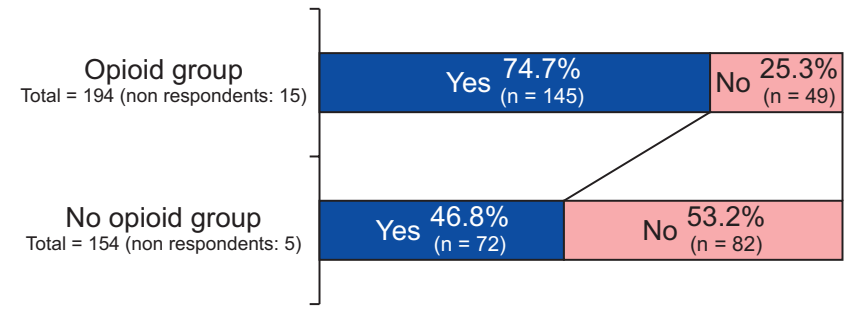

Fig. 8. Did you know that differences between medically prescribed opioids and illegally distributed drugs exist? (asked in both the opioid groups).

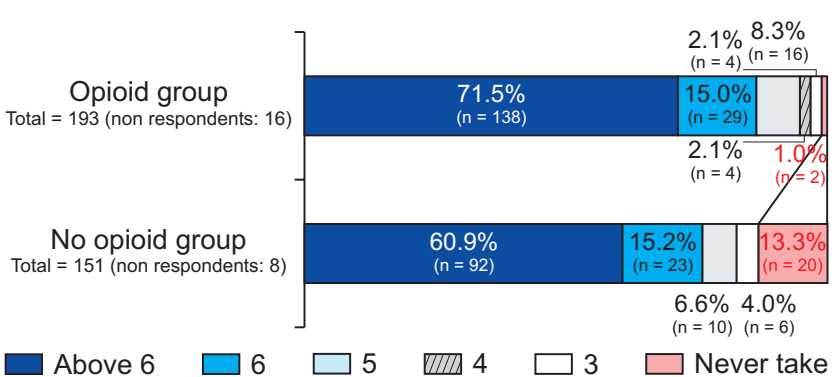

Fig. 9. What is the pain score at which you would start taking opioids if they are prescribed? (asked in both the opioid groups).

plied that they would never take opioids (Fig. 9).

\section{DISCUSSION}

Medical opioid consumption has increased worldwide [16]. Just as in Europe and North America, opioid use has increased in South Korea as well $[13,14]$. This survey revealed that many patients who were prescribed opioids at the pain clinic were those who experienced chronic noncancer pain (CNCP). Globally, doctors have struggled for a long time to treat CNCP because it can cause severe intractable pain, and reduces the quality of life. Doctors believe that the non-opioid treatment is limited, and thus, opioids $[16,17]$, which are mainly used for treating severe acute pain, postsurgical pain, and cancer pain, should be considered for the treatment [18]. The efficacy of opioids has been proven in studies on short-term opioid treatment for CNCP $[19,20]$. Although there was still debate about longterm opioid treatment for CNCP, The Cochrane Database of Systematic Reviews 2010 concluded that, despite the fact that pain relief varies from one study to another, long-term opioid therapy is clinically significant for CNCP [18]. There is also both moderate/high- and low-quality evidence suggesting that long-term opioid medication can lead to significant improvements in functional outcomes, including quality of life, in patients with CNCP.

Many studies have revealed the clinical benefits of opi- 
oid treatment on CNCP, but it should be used with caution. Some studies have expressed concerns about the safety of long-term opioid treatment, its side effects, and risk of addiction [17]. In this study, constipation, dizziness, nausea, and vomiting were found to be the most common side effects of opioids. Meta-analysis reported the following side effects of opioid medication: constipation (10\%-22\%), nausea (11\%-19\%), dizziness or vertigo (5\%-12\%), somnolence or drowsiness (5\%-13\%), vomiting (2\%-7\%), and dry skin, itching or pruritus $(1 \%-6 \%)$ [19].

In the opioid group, $2.0 \%$ of patients experienced the side effect of addiction. In the no opioid group, many patients who avoided opioids presented a concern regarding addiction. The subject of potential harms like misuse, abuse, and addiction should not be overlooked. Unlike other drugs, physiological dependence can arise in virtually all patients who are treated with chronic opioid therapy [21]. Several studies have been conducted on opioid addiction. In each study, the intoxication rate had been suggested to be from less than $1 \%$ to $3.3 \%$, and up to $4.4 \%$ among patients without prior opioid exposure $[18,22-$ 24]. Thinking broadly beyond addiction to aberrant drugrelated behaviors, recent rigorous studies have revealed that opioid use disorders occur in up to one-third of the patients receiving chronic opioid treatment [25]. Using the Opioid Risk Tool which includes questions about family history of substance abuse, personal history of substance abuse, age, history of preadolescent sexual abuse, and psychological disease, physicians can predict the probability of a patient displaying aberrant behaviors when opioids are prescribed for chronic pain [26]. Korean guidelines for opioid therapy for CNCP include administering a screening questionnaire for the possibility of opioid addiction before prescribing opioids [27]. Tools determining the risk of opioid addiction, if properly validated, would allow physicians to differentiate between patients who can be safely prescribed a long-term opioid therapy and those in whom the benefits are likely to be outweighed by the risks of the chronic opioid therapy [25]. Appropriate opioid prescription in selected patients, after careful identification of the opioid addiction risk, can minimize the risk of overdose, misuse, and addiction [28]. The Korean guidelines for opioid therapy for CNCP include identifying a patient's overall physical and addiction status prior to opioid prescription, obtaining informed consent and consent for opioid treatment, and selecting the type and amount of the selected drug for each stage of pain [27]. If doctors follow these treatment guidelines, they can use opioids with maximum benefit and minimal harm.

This survey was conducted to investigate a patient's perception regarding opioids and the insurance-associated limitations in Korea. Most patients in the opioid group had a neutral $(20.9 \%)$ or positive $(72.6 \%)$ perception of opioids. Only $6.5 \%$ of patients had negative perceptions. Although perception regarding opioids were not sought from the no opioid group patients, it was found that they had a considerably more negative perception than the opioid group patients. Thirty-nine percent of patients in the no opioid group said that they would not take opioids even if their physician prescribed them due to fear of addiction and side effects. This indicates that negative perceptions regarding opioids can lead patients to refuse opioid medication. A total of $71.5 \%$ and $60.9 \%$ patients in the opioid and no opioid groups, respectively, had a view that opioid medication must be consumed for a pain score of NRS 7 or higher. According to the Korean guidelines for opioid therapy for CNCP, opioid use may be considered the firstline treatment for patients experiencing severe pain [27]. NRS 7 and above is considered severe pain in patients with CNCP [29]. Hence, this can be one of the factors based on which doctors can decide whether to prescribe opioids. In the no opioid group, although $39.0 \%$ patients refused opioid prescription, $86.7 \%$ patients would start opioid medication based on their pain score. Therefore, a doctor can prescribe opioid medication with sufficient explanation to patients with severe pain. More than half of the patients in the no opioid group had obtained information regarding opioids from sources other than doctors. In the opioid group, $7.2 \%$ of the patients did not receive any explanation regarding opioids from their doctor. Although the rate was low in the opioid group, doctors should not forget to explain the opioid medication and its effect/side effects to their patients.

The difference between illegally distributed drugs and medically prescribed opioids was known to $74.7 \%$ patients in the opioid group but only to $46.8 \%$ patients in the no opioid group. Possibly, more than half of the patients in the no opioid group believed that opioid medication is as dangerous as illegally distributed drugs. This belief can be related to the fear of addiction and side effects (Fig. 6). The fear can be a barrier to the use of opioid medication.

According to public healthcare insurance system in Korea, the prescription days of opioids are limited to 1 month, and the insurable dose of opioids are limited for non-cancer pain. In the opioid group, more patients (51.2\%) thought that the limited prescription days are appropriate. However, $41.4 \%$ of patients thought that the limitation on prescription days was too severe, and needed to be increased for improved patient convenience and the opioid medication's safe usage. More patients (55.7\%) in the opioid group thought that the limited dosage of opioids should be increased for non-cancer pain. Especially $50 \%$ of CRPS patients thought that the limited dosage of opioids should be increased. This may be related to the insuf- 
ficient effect of the limited dose of opioids in severe pain patients.

This study has some limitations. First, this investigation was conducted among patients who agreed to the survey. Patients who disagreed with the questionnaire may have had a reason to be reluctant to do so. If it is due to an addiction to, or refusal of opioids, it should be considered in the interpretation of this investigation. Unfortunately, the number of people excluded due to the rejection of the questionnaire was not counted. Second, statistical analysis comparing the opioid and no opioid groups was not performed in this survey study. Hence, a comparative study in the future is warranted. Third, this survey included patients who agreed to it at the pain clinic, and thus, patients at a high risk of addiction were not excluded. Therefore, bias associated with opioid addicts' opinions regarding an increase in insurable days and dose may exist. However, not all $55.7 \%$ of the patients would have been addicts, and hence, we believe that the bias may be low. Only $2.0 \%$ of patients mentioned addiction as a side effect. To determine whether a patient is addicted, a doctor's opinion regarding the patient is crucial. Hence, future investigation on addiction must consider patients' as well as doctors' opinions.

In conclusion, this survey suggests that some patients have fears regarding opioid medication, related addiction, and side effects. However, the perception of opioids in most patients who are taking them was either neutral or positive. More patients in the opioid group and half of CRPS patients thought that the limited dosage of opioids should be increased for non-cancer pain. Even if opioids may be needed for severe pain patients, doctors should consider patient concerns regarding abuse or addiction before prescribing opioids.

\section{CONFLICT OF INTEREST}

No potential conflict of interest relevant to this article was reported.

\section{FUNDING}

No funding to declare.

\section{ORCID}

Cho Long Kim, https://orcid.org/0000-0002-7091-0910

Sung Jun Hong, https://orcid.org/0000-0002-2466-718X

Yun Hee Lim, https://orcid.org/0000-0003-2399-4768
Jae Hun Jeong, https://orcid.org/0000-0002-4341-572X

Ho Sik Moon, https://orcid.org/0000-0003-2298-7734

Hey Ran Choi, https://orcid.org/0000-0002-9899-0158

Sun Kyung Park, https://orcid.org/0000-0002-4133-5806

Jung Eun Kim, https://orcid.org/0000-0001-5125-3129

Hakjong You, https://orcid.org/0000-0001-9817-8891

Jae Hun Kim, https://orcid.org/0000-0002-6774-1829

\section{REFERENCES}

1. Gureje O, Von Korff M, Simon GE, Gater R. Persistent pain and well-being: a World Health Organization Study in primary care. JAMA 1998; 280: 147-51.

2. Ahacic K, Kåreholt I. Prevalence of musculoskeletal pain in the general Swedish population from 1968 to 2002: age, period, and cohort patterns. Pain 2010; 151: 206-14.

3. Toth C, Lander J, Wiebe S. The prevalence and impact of chronic pain with neuropathic pain symptoms in the general population. Pain Med 2009; 10: 918-29.

4. Breivik H, Collett B, Ventafridda V, Cohen R, Gallacher D. Survey of chronic pain in Europe: prevalence, impact on daily life, and treatment. Eur J Pain 2006; 10: 287-333.

5. Fine PG. Long-term consequences of chronic pain: mounting evidence for pain as a neurological disease and parallels with other chronic disease states. Pain Med 2011; 12: 9961004.

6. Dworkin RH, O'Connor AB, Audette J, Baron R, Gourlay GK, Haanpää ML, et al. Recommendations for the pharmacological management of neuropathic pain: an overview and literature update. Mayo Clin Proc 2010; 85(3 Suppl): S3-14.

7. Attal N, Cruccu G, Baron R, Haanpää M, Hansson P, Jensen TS, et al. EFNS guidelines on the pharmacological treatment of neuropathic pain: 2010 revision. Eur J Neurol 2010; 17: 1113-e88.

8. Kim YD. Opioid: toward an effective strategy for better use. Korean J Pain 2019; 32: 67-8.

9. Moore RA, McQuay HJ. Prevalence of opioid adverse events in chronic non-malignant pain: systematic review of randomised trials of oral opioids. Arthritis Res Ther 2005; 7: R1046-51.

10. Sun VC, Borneman T, Ferrell B, Piper B, Koczywas M, Choi K. Overcoming barriers to cancer pain management: an institutional change model. J Pain Symptom Manage 2007; 34: 359-69.

11. Maltoni M. Opioids, pain, and fear. Ann Oncol 2008; 19: 5-7.

12. Baik JS. Guidelines for prescribing opioids for chronic noncancer pain in Korea: can you overcome "opiophobia"? Korean J Pain 2017; 30: 1-2.

13. Han T. Opioids in cancer and non-cancer pain management in Korea: the past, present and future. Eur J Pain 2001; 5 Suppl A: 73-8. 
14. Oh TK, Jeon YT, Choi JW. Trends in chronic opioid use and association with five-year survival in South Korea: a population-based cohort study. Br J Anaesth 2019; 123: 655-63.

15. Lee JH. The opioid epidemic and crisis in US: how about Korea? Korean J Pain 2019; 32: 243-4.

16. Consensus Statement from the American Academy of Pain Medicine and the American Pain Society. The use of opioids for the treatment of chronic pain. J Pharm Care Pain Symptom Control 2010; 6: 97-102.

17. Kalso E, Edwards JE, Moore RA, McQuay HJ. Opioids in chronic non-cancer pain: systematic review of efficacy and safety. Pain 2004; 112: 372-80.

18. Noble M, Treadwell JR, Tregear SJ, Coates VH, Wiffen PJ, Akafomo C, et al. Long-term opioid management for chronic noncancer pain. Cochrane Database Syst Rev 2010; 2010: CD006605.

19. Furlan AD, Sandoval JA, Mailis-Gagnon A, Tunks E. Opioids for chronic noncancer pain: a meta-analysis of effectiveness and side effects. CMAJ 2006; 174: 1589-94.

20. Eisenberg E, McNicol ED, Carr DB. Efficacy and safety of opioid agonists in the treatment of neuropathic pain of nonmalignant origin: systematic review and meta-analysis of randomized controlled trials. JAMA 2005; 293: 3043-52.

21. Ballantyne JC. Opioid analgesia: perspectives on right use and utility. Pain Physician 2007; 10: 479-91.

22. Portenoy RK, Farrar JT, Backonja MM, Cleeland CS, Yang K, Friedman M, et al. Long-term use of controlled-release oxy- codone for noncancer pain: results of a 3-year registry study. Clin J Pain 2007; 23: 287-99.

23. Anderson VC, Burchiel KJ. A prospective study of long-term intrathecal morphine in the management of chronic nonmalignant pain. Neurosurgery 1999; 44: 289-300.

24. Fishbain DA, Cole B, Lewis J, Rosomoff HL, Rosomoff RS. What percentage of chronic nonmalignant pain patients exposed to chronic opioid analgesic therapy develop abuse/ addiction and/or aberrant drug-related behaviors? A structured evidence-based review. Pain Med 2008; 9: 444-59.

25. Juurlink DN, Dhalla IA. Dependence and addiction during chronic opioid therapy. J Med Toxicol 2012; 8: 393-9.

26. Webster LR, Webster RM. Predicting aberrant behaviors in opioid-treated patients: preliminary validation of the Opioid Risk Tool. Pain Med 2005; 6: 432-42.

27. Kim ED, Lee JY, Son JS, Byeon GJ, Yeo JS, Kim DW, et al. Guidelines for prescribing opioids for chronic non-cancer pain in Korea. Korean J Pain 2017; 30: 18-33.

28. Kahan M, Wilson L, Mailis-Gagnon A, Srivastava A; National Opioid Use Guideline Group. Canadian guideline for safe and effective use of opioids for chronic noncancer pain: clinical summary for family physicians. Part 2: special populations. Can Fam Physician 2011; 57: 1269-76, e419-28.

29. Woo A, Lechner B, Fu T, Wong CS, Chiu N, Lam H, et al. Cut points for mild, moderate, and severe pain among cancer and non-cancer patients: a literature review. Ann Palliat Med 2015; 4: 176-83. 


\section{Appendix. Questionnaire about opioids}

Investigation of patient's perception of opioids (English version)

1. What is your sex?

(1) female (2) male

2. What is your age?

(1) $0-10 s$ (2) $20 s$ (3) $30 s$ (4) $40 s$ (5) $50 s$ (6) $60 s$ (7) 70s (8) $\geq 80 s$

3. What is the disease you are suffering from?

(1) spinal or joint pain (2) CRPS (complex regional pain syndrome) (3) postherpetic neuralgia

(4) fibromyalgia (5) peripheral neuropathy (6) cancer pain

4. How long have you been treated in a pain clinic?

(1) $<6 \mathrm{mo}$ (2) $6 \mathrm{mo} \leq,<1 \mathrm{yr}$ (3) $1 \mathrm{yr} \leq,<3 \mathrm{yr}$ (4) $3 \mathrm{yr} \leq,<5 \mathrm{yr}$ (5) $\geq 5 \mathrm{yr}$

5. Have you ever been prescribed opioids?

(1) Yes $\rightarrow$ answer 6-1, 6-2, 6-3, 6-4, 6-5, 6-6, 6-7, 6-8, 6-9, 6-10, and go to 8, 9

(2) No $\rightarrow$ answer 7-1, 7-2, 7-3, and go to 8, 9

6-1. What are the most severe side effects that you have experienced?

(1) constipation (2) nausea, vomiting (3) dizziness (4) dysuria (5) addiction (6) others (7) none

6-2. Did your doctor tell you about opioids and explain the side effects?

(1) well explained (2) roughly explained (3) never explained

6-3. What is your perception of opioid medication?

(1) very positive (2) positive (3) neutral (4) negative (5) very negative

6-4. How many weeks are you prescribed opioids at once?

(1) 1 week (2) 2 weeks (3) 3 weeks (4) 4 weeks (5) above 4 weeks

6-5. In Korea, prescription of opioids for non-cancer pain is limited to 30 days related to public health insurance. What do you think about this limit on prescription days?

(1) suitable (2) need to be increased (3) need to be decreased

6-6. If you think the limitation of prescription days should be increased, then tell us why?

(1) for patient's convenience

(2) for doctor's convenience

(3) There is no need to limit because it is a safe medicine

6-7. If you think the limitation of prescription days should decrease, then tell us why?

(1) concerns about abuse and addiction

(2) need of monitoring for effects and side effects

(3) others

6-8. For cancer pain, there is no restriction on the dosage of opioids, but for non-cancer pain, there is a limit on the opioid dosage of public health insurable prescription (insurance coverage). What do you think about the limit on the opioid dosage of public health insurance in non-cancer pain?

(1) suitable (2) need to be increased (3) need to be decreased 
6-9. If you think insurable prescription dosages need to be increased, then tell us why?

(1) economic loss due to capacity limitation

(2) reduction of analgesic effect due to drug resistance

(3) there is no need to limit because it is a safe medicine

(4) others

6-10. If you think insurable prescription dosages need to be decreased, then tell us why?

(1) concerns about abuse and addiction (2) need of monitoring for effects and side effects (3) others

7-1. If your physician tells you the need to prescribe opioids for pain control, would you take it?

(1) Yes (2) No

7-2. If you refuse the prescription of opioid, why do you refuse to take opioids?

(1) fear of side effects (2) fear of addiction (3) others

7-3. Where do you get information about opioids?

(1) from doctors (2) from friends (3) from mass media (4) from the internet (5) others

8. Did you know that there are differences between medically prescribed opioids and illegally distributed drugs?

(1) Yes (2) No

9. What is the pain score at which you would start taking opioids if they are prescribed?

(0: No pain-10: The greatest pain one can think of)

(1) 3 (2) 4 (3) 5 (4) 6 (5) above 6 (6) never take

마약성 진통제에 대한 환자의 인식도 조사(Korean version)

1. 환자분의 성별은 무엇입니까?

(1) 여자 (2) 남자

2. 환자분의 나이는 어떻게 되십니까?

(1) 20 세 미만 (2) 20 대 (3) 30 대 (4) 40 대 (5) 50 대 (6) 60 대 (7) 70 대 (8) 80 세 이상

3. 않고 계신 질환명(병명)은 무엇입니까?

(1) 척추 관절 통증 (2) 복합부위통증증후군 (3) 대상포진 후 신경통 (4) 섬유근육통

(5) 말초신경병증 (6) 암성 통증

\section{4. 통증 클리닉을 다닌 기간은 얼마나 되십니까?}

(1) 6개월 미만 (2) 6개월 이상 1년 미만 (3) 1년 이상 3년 미만 (4) 3년 이상 5년 미만 (5) 5년 이상

5. 마약성 진통제를 처방 받아보신 적 있으십니까?

(1) 예 $\rightarrow 6-1,6-2,6-3,6-4,6-5,6-6,6-7,6-8,6-9,6-10$ 답변 후 8, 9

(2) 아니오 $\rightarrow 7-1,7-2,7-3$ 답변 후 8,9

6-1. 환자분이 경험해본 가장 심한 부작용은 무엇입니까?

(1) 변비 (2) 오심, 구토 (3) 어지러움 (4) 배뇨장애 (5) 중독 (6) 기타 (7) 없음

6-2. 의사가 마약성 진통제와 그 부작용에 관한 내용을 잘 설명하였습니까?

(1) 잘 설명해주었음 (2) 대강 설명해주었음 (3) 전혀 설명하지 않았음

6-3. 마약성 진통제에 대한 인식은 어떻게 되십니까?

(1) 매우 긍정적 (2) 긍정적 (3) 그저 그렇다 (4) 부정적 (5) 매우 부정적 
6-4. 한번에 마약성 진통제를 몇 주치 처방받으십니까?

(1) 1주 (2) 2주 (3) 3주 (4) 4주 (5) 4주 이상

6-5. 현재 비암성 통증에 대해 마약성 진통제 처방 기간은 최대 30일까지로 제한되어 있습니다. 이에 대해 어떻게 생각하십 니까?

(1) 적절하다 (2) 처방 일수를 늘렸으면 한다 (3) 처방 일수를 줄였으면 한다

6-6. 처방 일수를 늘려야 한다면 가장 큰 이유는?

(1) 환자의 편의 (2) 의사 편의 (3) 안전한 약이므로 제한을 할 필요가 없다

6-7. 처방 일수를 줄여야 한다면 가장 큰 이유는?

(1) 오남용 및 중독에 대한 우려 (2) 효과 및 부작용에 대한 모니터링 필요 (3) 기타

6-8. 암성 통증에 대해서는 마약성 진통제 용량의 제한 없이 보험 급여가 가능하지만, 비암성통증의 경우 마약성 진통제를 처방할 때 보험으로 처방 가능한 용량의 제한이 있습니다(보험 보장). 비암성 통증에서의 처방 용량 제한에 대해 어떻게 생각 하십니까?

(1) 적절하다 (2) 처방제한 용량을 더 늘려야 한다 (3) 처방제한 용량을 더 제한해 줄여야 한다

6-9. 처방 제한 용량을 늘려야 한다면 가장 큰 이유는?

(1) 용량 제한으로 보험 적용 안 되어 경제적 손실

(2) 약물 내성으로 인한 진통 효과 감소

(3) 안전한 약이므로 제한을 할 필요가 없다

(4) 기타(구체적으로 적어주세요)

6-10. 처방제한 용량을 줄여야 한다면 그 이유는?

(1) 오남용에 대한 우려

(2) 효과 및 부작용에 대한 모니터링 필요

(3) 기타(구체적으로 적어주세요)

7-1. 의사가 환자분의 통증 조절을 위해 마약성 진통제를 처방하겠다고 하면 복용하시겠습니까? (1) 예 (2) 아니오

7-2. 복용하지 않겠다면 이유는 무엇입니까?

(1) 부작용이 무서워서 (2) 마약성 진통제에 중독될까(의존하게 될까) 걱정돼서 (3) 기타

7-3. 마약성 진통제에 대한 정보를 주로 어디서 얻으십니까?

(1) 의사 (2) 지인 (3) TV, 신문 등 매체 (4) 인터넷 (5) 기타

8. 일반 마약과 마약성 진통제에 차이가 있다는 점을 알고 계십니까?

(1) 예 (2) 아니오

9. 사람이 경험할 수 있는 최대의 통증이 10점이라면 몇 점의 통증이 있으실 때 마약성 진통제를 복용하시겠습니까?

(1) 3점 (2) 4점 (3) 5점 (4) 6점 (5) 7점 이상 (6) 절대 안 먹는다 